\title{
Emplacement of magmatic Cu-Au-Te(-Ni-PGE) sulfide blebs in alkaline mafic rocks of the Mordor Complex, Northern Territory, Australia
}

\author{
David A. Holwell ${ }^{1}$ (D) $\cdot$ Daryl E. Blanks ${ }^{1}$ (D) \\ Received: 19 June 2020 / Accepted: 31 August 2020 / Published online: 29 September 2020 \\ (C) The Author(s) 2020
}

\begin{abstract}
Magmatic Ni-Cu-PGE sulfide mineralisation is mostly confined to tholeiitic to komatiitic mafic-ultramafic intrusions, yet there have been an increasing number of occurrences recorded in alkaline-ultramafic, post-collisional magmatic systems, particularly in the lower and middle crust that generally display a characteristic $\mathrm{Cu}-\mathrm{Au}$-Te enrichment over more conventional Ni-Cu(-PGE) mineralisation. The Mordor Alkaline Igneous Complex, Australia, is a mid-crustal, zoned alkaline complex comprised of a syenite body with an alkaline mafic-ultramafic subcomplex containing dunites, wehrlites and shonkinites. Sulfide mineralisation is present either in thin, PGE-enriched stratiform 'reefs' within layered ultramafics in the centre of the subcomplex, or in thicker zones of $\mathrm{Cu}(-\mathrm{Au}-\mathrm{PGE}-\mathrm{Te})$ sulfide hosted by phlogopite-rich shonkinites towards the intrusion margins. This latter style comprises blebs of pyrite, chalcopyrite and minor millerite and PGE tellurides formed from the cooling of a $\mathrm{Cu}$-dominant sulfide liquid. Primary igneous calcite is present in intimate association with the sulfide. We note that the circular nature of the complex, with a dunite core and shonkinite rim with chalcophile element mineralisation, is comparable to the pipe-like, intracratonic, alkaline-ultramafic Aldan Shield intrusions in Russia. As such, Mordor may have an intracratonic rather than post-collisional affinity. Nevertheless, sulfide mineralisation is typical of other alkaline-hosted occurrences, with a $\mathrm{Cu}$-Au-Te-rich signature, low $\mathrm{Ni}$ contents and textural association with calcite, supporting models of chalcophile metal and $\mathrm{S}$ fluxing alongside carbonate in alkaline systems derived from low degrees of partial melting of hydrous and carbonated mantle sources. Mordor illustrates that alkaline igneous rocks are prospective for magmatic $\mathrm{Cu}$-Au-PGE-Ni sulfide mineralisation, and the classic 'marginal base metal- and sulfide-rich' and 'stratiform PGE-rich and sulfide-poor' mineralisation styles may both be found in such intrusions.
\end{abstract}

Keywords Magmatic sulfides $\cdot$ Alkaline $\cdot$ Ultramafic $\cdot$ Ni-Cu-PGE $\cdot$ Carbonate $\cdot$ Mordor

\section{Introduction}

Magmatic Ni-Cu-PGE sulfide deposits are generally located within mafic-ultramafic complexes formed from mantle-

Editorial handling: W. D. Maier

Electronic supplementary material The online version of this article (https://doi.org/10.1007/s00126-020-01015-2) contains supplementary material, which is available to authorized users.

David A. Holwell

dah29@1e.ac.uk

1 Centre for Sustainable Resource Extraction, School of Geography, Geology and the Environment, University of Leicester, University Road, Leicester LE1 7RH, UK derived melts in rift and/or plume settings and can be grouped into three main categories: Ni deposits hosted by komatiites; $\mathrm{Ni}-\mathrm{Cu}$-dominant deposits in ultramafic-mafic intrusions such as chonoliths, pipes and conduits; and PGE-dominant deposits in layered ultramafic-mafic complexes (e.g. Barnes et al. 2016, 2017). Exploration for large Ni-sulfide deposits is focussed on craton margins, which have a well-established spatial control over many of the largest and most well-studied deposits (e.g. Noril'sk, Voisey's Bay, Thompson Nickel Belt, Raglan, e.g. Begg et al. 2010), whereas the more PGErich bodies are generally found in intracratonic settings (e.g. Maier and Groves 2011).

However, there has been a growing recognition of magmatic sulfide deposits and occurrences in a broader range of settings, such as collisional orogenic belts, e.g. Finnish nickel 
belt (e.g. Makkonen et al. 2017), Aguablanca in Spain (Piña et al. 2010), Älgliden in Sweden (Cordier et al. 2019) and deposits of the Central Asian Orogenic Belt in central China (e.g. Huangshandong; Deng et al. 2014; Lu et al. 2019). Additionally, unconventional styles of Ni-Cu-PGE sulfide mineralisation are being increasingly recognised in more alkaline and hydrous ultramafic-mafic magmatic settings, notably those related to post-collisional extension (Holwell et al. 2019). These include lower crustal intrusions such as alkaline and hydrous ultramafic pipes in the Ivrea zone, Italy (e.g. Sessa et al. 2017), mid-crustal composite intrusions of syenites and alkaline mafic-ultramafic rocks (e.g. Coldwell Complex, Canada; Heaman and Machado 1992; Sron Garbh, Scotland; Graham et al. 2017; Loch Borralan and Loch Ailsh, Scotland; Styles et al. 2004; and Okiep, South Africa; Maier et al. 2012) and $\mathrm{Cu}$ in rare alkaline-phoscoritecarbonatite complexes (e.g. Phalaborwa, South Africa, and Kovdor, Russia; Rudashevsky et al. 2004).

A suite of Ni-Cu-PGE sulfide occurrences in post-collisional settings, defined by the alkaline nature of the host magmas, and a geochemical signature that is generally more enriched in $\mathrm{Cu}$, $\mathrm{Au}$ and Te compared with most ultramafic-mafic hosted deposits, have been investigated by Holwell et al. (2019) and Blanks et al. (2020). These occurrences are typically hosted by rocks that are the product of low $(<10 \%)$-degree partial melts that appear to be linked by an intimate association between sulfide and carbonate of mantle origin, and Blanks et al. (2020) proposed that $\mathrm{CO}_{2}$ can aid the physical transport of mantle sulfides up into the lower and mid-crust. The host intrusions for these occurrences span the lithosphere and are generally small (e.g. Sron Garbh and Ivrea pipes are both tens to a few hundreds of metres in thickness), yet they can occur over significant areas, such as the Coldwell Complex, Canada, which has an area of $\sim 350 \mathrm{~km}^{2}$, although the mineralised mafic-ultramafic rim makes up only a small percentage of the complex. One of the largest examples of exposed alkaline mafic-ultramafic rocks is in the mid-crustal Mordor Alkaline Igneous Complex (MAIC), in Northern Territory, Australia (Langworthy and Black 1978; Barraclough 1981; Hoatson et al. 2005; Barnes et al. 2008). The MAIC is a zoned intrusion comprising an ultramafic-mafic portion and a slightly offset syenitic rim, covering a total area of $35 \mathrm{~km}^{2}$. The ultramaficmafic portion is host to two styles of magmatic sulfide mineralisation: disseminated stratiform PGE 'reef' style mineralisation in the layered alkaline-ultramafic rocks in the centre of the complex, which have been described by Barnes et al. (2008); and more voluminous blebby $\mathrm{Cu}$-(Au-PGE-Ni) sulfides in mafic syenites, or 'shonkinites', which have never been studied in detail. Here we describe the nature of the shonkinite-hosted mineralisation for the first time, compare it with alkaline-hosted deposits elsewhere and assess the significance of this deposit in terms of the mid-crustal expression of magmatic sulfides in alkaline magmatic systems.

\section{Regional geology}

The Mordor Alkaline Igneous Complex, located $\sim 65 \mathrm{~km}$ eastnortheast of Alice Springs in Northern Territory, Australia, was emplaced into the high-grade Arltunga granitic gneisses and granitic intrusives of the Palaeoproterozoic Arunta Block. The Arunta Block is a multiply deformed and metamorphosed Precambrian-Palaeozoic basement terrane in a belt that spans $200,000 \mathrm{~km}^{2}$ in central Australia (Fig. 1a). A number of wellexposed mafic-ultramafic intrusions occur throughout the Arunta Block and are described and dated by Hoatson et al. (2005), who identified five major tholeiitic magmatic events at $\sim 1810, \sim$ $1780, \sim 1690$ and $\sim 1635$ Ma, plus a much younger Palaeozoic event. An exception to this is the MAIC, which represents a more alkaline event at $1133 \pm 5 \mathrm{Ma}$ (U-Pb zircon SHRIMP date; Claoué-Long and Hoatson 2005), which is poorly understood, though may be part of the regional $1150-1130 \mathrm{Ma}$ 'Teapot' thermal event (Black et al. 1983). The MAIC is situated close to the Woolanga Gravity Lineament (Fig. 1a), an inferred deepseated NW-SE trending structure (Langworthy and Black 1978).

The Neoproterozoic Amadeus Basin sediments have been thrust over the MAIC and Arunta basement rocks, such that the ( $820 \mathrm{Ma})$ Heavitree Quartzite unconformably overlies Arltunga tonalitic gneiss host rocks and the MAIC itself. Erosion of the quartzites has led to a remarkable geomorphological feature that forms a three-sided box-shaped canyon (Fig. 1b). This inspired Bureau of Mineral Resources, Geology and Geophysics geologists to name the area Mordor Pound due to the similarity to the maps of the fictional Mordor in Lord of the Rings (Tolkien 1954). In addition, a small ultramafic hill in the centre of the MAIC was named 'Mount Doom' (Fig. 1b, c).

\section{Geology of the Mordor Alkaline Igneous Complex}

The geology and some of the mineralisation of the Mordor Alkaline Igneous Complex have been described by Langworthy and Black (1978), Barraclough (1981), Anderson and Smith (2003) and Barnes et al. (2008) and are summarised here. The complex covers an area of $\sim 35 \mathrm{~km}^{2}$, with an outer coarse grained porphyritic syenite in the northwestern part, intruded by a zoned alkaline mafic-ultramafic complex that covers $\sim 13 \mathrm{~km}^{2}$ of the total area of the complex. The mafic-ultramafic subcomplex, referred to as the Mordor mafic-ultramafic intrusion, or MMUI, by Barnes et al. (2008), comprises layered pyroxene-rich cumulates with variable amounts of other cumulus phases including phlogopite, apatite, olivine, ilmenite and Kfeldspar.

The mafic-ultramafic subcomplex is largely comprised of mafic syenites referred to as 'shonkinites' with a number of outcropping pods of layered olivine- and pyroxene-rich ultramafic cumulates (dunites and wehrlites) that form prominent 

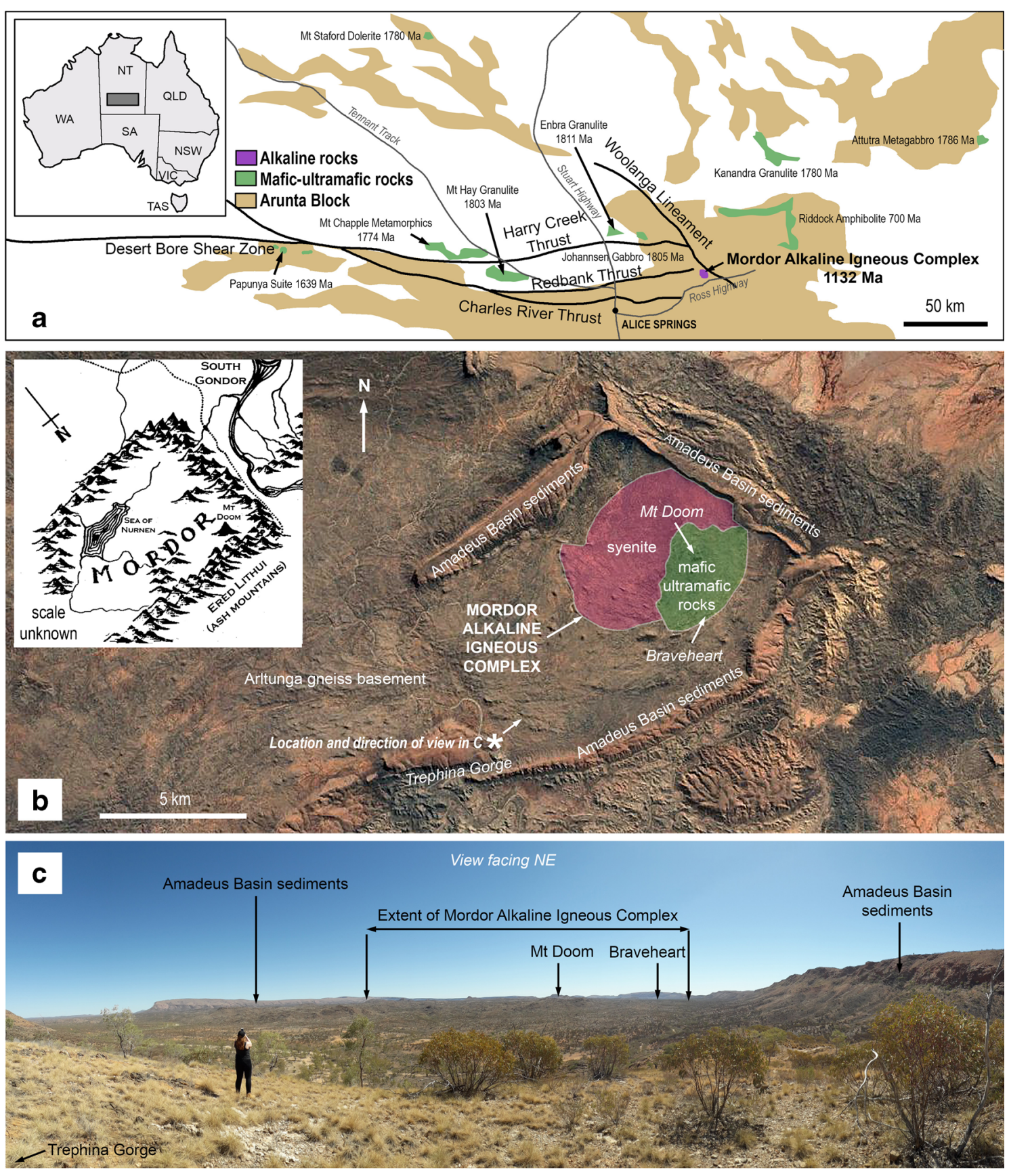

Fig. 1 a Regional geological map of the Arunta block showing maficultramafic intrusions and the Mordor Alkaline Igneous Complex (after Hoatson et al. 2005). b Satellite image showing the geomorphology of the Mordor Alkaline Igneous Complex and surrounding hills of the Amadeus

topographic features in the central part, the highest of which is Mount Doom (Figs. 1 and 2). The northwestern and central part is largely comprised of phlogopite-rich pyroxene-syenites ('mafic shonkinites'), with a typical modal mineral assemblage of phlogopite $(40-50 \%)+$ augite $(30-40 \%)+\mathrm{K}$ feldspar $(5-10 \%)+$ apatite $(5-10 \%)+$ zircon + oxides (magnetite-ilmenite). A zone of characteristic 'porphyritic shonkinites,' which contain K-feldspar phenocrysts (up to $50 \%$ ) in a matrix identical to the mafic shonkinites, is present
Basin sediments. Inset: map of the fictional Mordor from Tolkien (1954) illustrating the origin of the name. $\mathbf{c}$ View of the Mordor Alkaline Igneous Complex and surrounding Amadeus Basin sediments from Trephina Gorge

around the edge of the mafic-ultramafic subcomplex and is thickest at the southeastern margin, including the 'Braveheart' area (Figs. 1 and 2), which includes an ironstone gossan (Fig. 2b) with underlying magmatic $\mathrm{Cu}$-dominant sulfide mineralisation that we describe in this paper.

Pegmatitic veins and dykes, often comprised of carbonate and/or quartz-feldspar, cross cut the complex, commonly in a NE-SW to E-W orientation within the mafic-ultramafic subcomplex (Barraclough 1981). Four types of carbonate-rich 


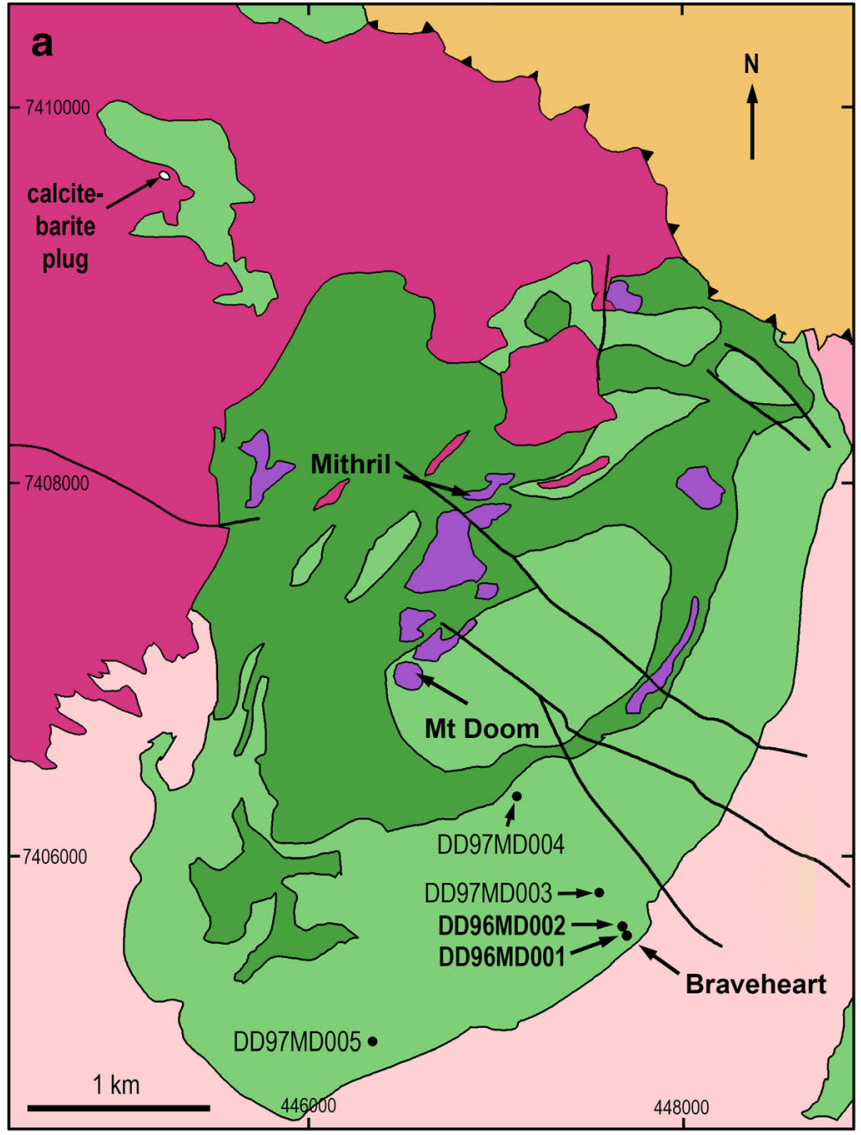

Neoproterozoic sediments Amadeus Basin:

Heavitree Quartzite
Mordor Alkaline Igneous Complex

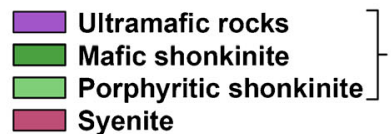

Fig. 2 a Geological map of the mafic-ultramafic intrusions of the Mordor Alkaline Igneous Complex, showing drillhole locations referred to in this study from the Braveheart area. Sampled drillholes are shown in bold. b

rocks were recognised by Langworthy and Black (1978): (1) veinlets of serpentinised apatite-phlogopite-bearing ultramafic rocks clasts in a hydrothermal calcite matrix breccia, thought to be much younger than the complex at $\sim 400 \mathrm{Ma}$; (2) dyke-like bodies of phlogopite-calcite rock up to $0.5 \mathrm{~m}$ in thickness that resemble carbonatites, at least in hand specimen; (3) a 10-mdiameter circular plug of crystalline calcite with a barite core (Fig. 2a); and (4) dykes of quartz-chlorite-calcite. Although some of these were considered to be carbonatitic in origin (Barraclough 1981), Langworthy and Black (1978) argued against such an origin on the basis of trace element and $\mathrm{Sr}$ isotopic ratios, suggesting instead they originated from leaching of the ultramaficmafic host rocks.

\section{Mineralisation and exploration history}

The MAIC has been subject to exploration activities for a number of commodities since the late 1960s, not only for magmatic

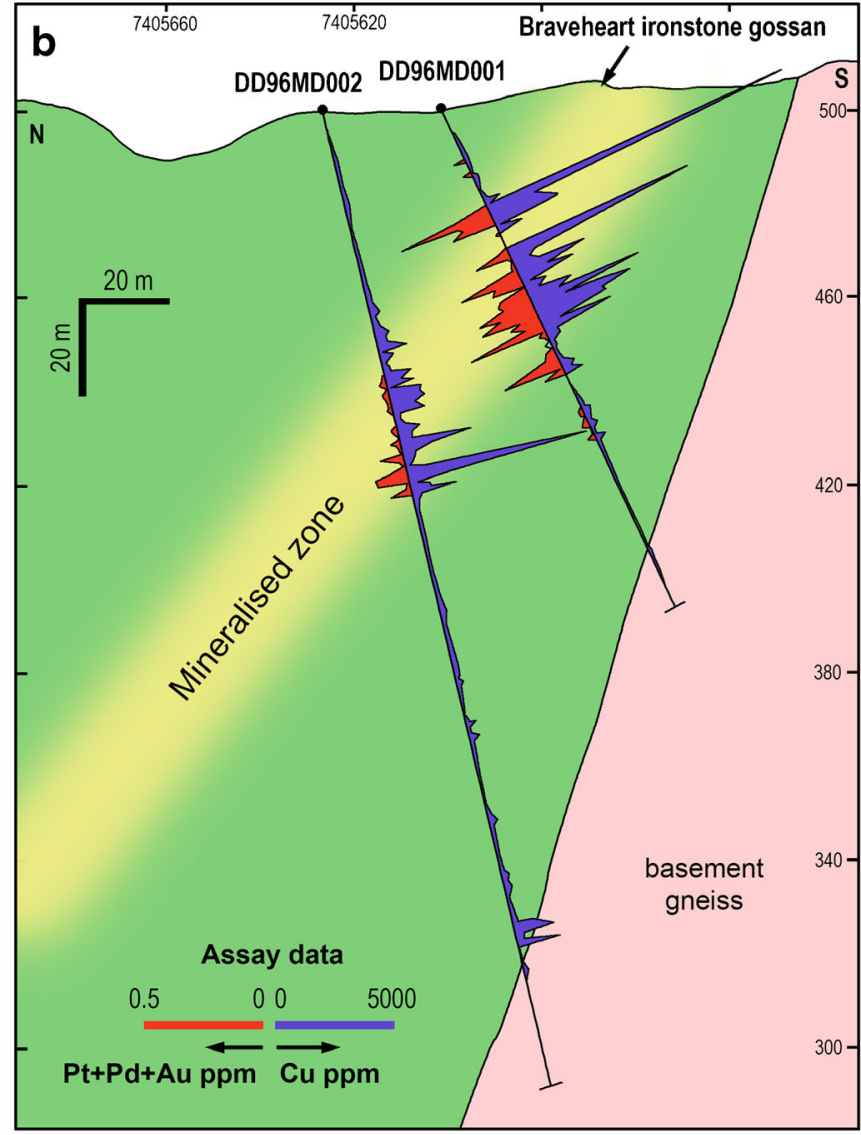

Palaeoproterozoic basement

Arltunga Gneiss Complex

Mafic-Ultramafic Intrusion

Geological cross section of the mineralised zone in the Braveheart area, with downhole $\mathrm{Cu}$ and $\mathrm{Pt}+\mathrm{Pd}+\mathrm{Au}$ assays (after Anderson and Smith 2003)

Ni-Cu-PGE mineralisation but also vermiculitic phlogopite, diamonds, $\mathrm{U}$ and rare earth elements (REE). The most recent drilling by Tanami Gold in 2002 identified 'reef' style PGE mineralisation with fine disseminated $\mathrm{Cu}-\mathrm{Ni}$ sulfides located within the layered ultramafic cumulates in the central part of the MMUI around Mount Doom and Mithril (Fig. 2a); including a 2-m intersection with $1.1 \mathrm{ppm} \mathrm{Pt}+\mathrm{Pd}+\mathrm{Au}$ within an 8-m zone of $0.67 \mathrm{ppm} \mathrm{Pt}+\mathrm{Pd}+\mathrm{Au}$ (Anderson and Smith 2003). This mineralisation was subsequently described by Barnes et al. (2008) who report $\mathrm{Cu}$-Au-Pt-Pd sulfides in stratiform disseminated layers within the basal parts of cyclic units.

However, the first significant exploration, involving surface geochemistry; radiometrics, airborne EM ground magnetics and IP geophysics; and drilling, was in 1996-1997 by CRA Exploration Pty Ltd. (CRAE). CRAE drilled 5 diamond drillholes and 12 reverse circulation holes over the porphyritic shonkinites in the Braveheart area in search of sulfide mineralisation associated with a surface ironstone (McCoy 
et al. 1997; Wilkinson et al. 1998). Some of the drilling was designed to test IP anomalies, although the majority of drilling in the Braveheart area focussed on the ironstone (Fig. 2a, b). The shonkinites were found to contain up to $10 \%$ blebby sulfide mineralisation (pyrrhotite and chalcopyrite with some pyrite) with the best results achieved from drillhole DD96MD001 (Fig. 2b), which returned $30.4 \mathrm{~m}$ at $0.25 \% \mathrm{Cu}$, including $1 \mathrm{~m}$ at $1.4 \% \mathrm{Cu}, 0.3 \% \mathrm{Ni}, 0.1 \mathrm{~g} / \mathrm{t} \mathrm{Au}$ and $0.4 \mathrm{~g} / \mathrm{t} \mathrm{Pt}+\mathrm{Pd}$ (McCoy et al. 1997). An additional but weaker mineralised section was identified in another hole (DD96MD002; Fig. 2b), with a further three holes drilled in 1997 (DD97MD003-5) that did not intersect any significant mineralisation (Fig. 2b). No studies have thus far been published on this mineralisation style, which forms the focus of this paper.

\section{Samples and methods}

A total of eight quarter core samples of $20 \mathrm{~cm}$ in length were taken from the mineralised intersection within DD96MD001 at Braveheart, drilled by CRA Exploration in 1996, and now housed by the Northern Territory Geological Survey (NTGS) Core Facility in Alice Springs. The location of the drillholes sampled in this study is shown in Fig. 2. Sampling was facilitated by the NTGS in November 2019. Polished thin sections of each sample were created at the University of Leicester. Platinum-group minerals were identified on a Zeiss SIGMA 300VP scanning electron microscope (SEM) equipped with two Bruker XFlash 6|60 energydispersive spectroscopy detectors (EDX), with 126-eV energy resolution.

Bulk rock assays from samples drilled by CRAE, reported in McCoy et al. (1997) from DD96MD001 and DD96MD002, are utilised in this paper and presented in Supplementary Table 1. Analysis was undertaken at Amdel Laboratories Ltd. in Alice Springs, with Pt, Pd and Au by fire assay followed by atomic absorption spectrometry and other elements including $\mathrm{Co}, \mathrm{Cu}, \mathrm{Cr}$ and $\mathrm{Ni}$ (used in this paper) by inductively coupled plasma-mass spectrometry.

\section{Petrology of the mineralised shonkinites}

The shonkinites make up the majority of the mafic-ultramafic subcomplex and are comprised of phlogopite, clinopyroxene (augite) and $\mathrm{K}$-feldspar with up to 10 modal \% apatite, olivine and accessory magnetite-ilmenite and zircon. All the rocks within the sections sampled contain this essential mineralogy in varying proportions (Fig. 3). Phlogopite typically makes up 20-50 modal $\%$ of the assemblage (Fig. 3a, b), and apatite is a cumulus phase and forms euhedral crystals included in all other phases (e.g. Fig. 3b). Calcite is occasionally present as an interstitial phase, usually close to sulfide blebs (Fig. 3c), some of which also contain interstitial calcite (Fig. 3d). Where $\mathrm{K}$-feldspar crystals are large and become a major modal component, the texture becomes porphyritic (Fig. 3e). The lowest part of the mineralised zone (which contains the highest PGE/ base metal ratios) is made up of a highly porphyritic rock with large $(<15 \mathrm{~mm}) \mathrm{K}$-feldspar crystals surrounded by phlogopite-apatite-sulfide (Fig. 3f).

\section{Bulk rock geochemistry of the mineralisation}

\section{Downhole geochemistry}

Figure 4 shows the downhole variations in $\mathrm{Cu}, \mathrm{Ni}, \mathrm{Co}, \mathrm{Cr}, \mathrm{Pt}$, $\mathrm{Pd}$ and $\mathrm{Au}$ in DD96MD001 and DD96MD002 (data from McCoy et al. 1997). The mineralised zone in DD96MD001 is clearly marked by elevated $\mathrm{Cu}$ (>150 ppm) between 22 and $80 \mathrm{~m}$, with the main $\mathrm{Cu}$-mineralised zone between 22 and $54 \mathrm{~m}$, where $\mathrm{Cu}$ values are consistently $>500 \mathrm{ppm}$ and up to 13,900 ppm over intersections of several metres (Fig. 4a). The $\mathrm{Ni}$ content of the mineralised zone is relatively low in comparison, mostly $<500 \mathrm{ppm}$, with the exception of a peak (2750 ppm) at $24 \mathrm{~m}$, towards the very top of the zone (Fig. 4a) that coincides with the highest $\mathrm{Cu}$ value. Cobalt correlates well with $\mathrm{Ni}$, with its highest values also in the upper portion of the mineralised zone, and whilst $\mathrm{Cr}$ is elevated in the mineralised zone, it does not necessarily correlate with the base metals (Fig. 4b). Precious metals are elevated within the same zone with a peak at the very top but also a consistently elevated zone around 45-55 m (Fig. 4c), where Au peaks at $0.38 \mathrm{ppm}$ in the interval $49.15-50.00 \mathrm{~m}$ within highly porphyritic shonkinite (Fig. 3f). There is also a peak in both $\mathrm{Pt}$ and $\mathrm{Pd}$ just below this at 53.00-54.00 $\mathrm{m}$ with a total $\mathrm{Pt}+\mathrm{Pd}$ grade of $0.34 \mathrm{ppm}$ within a sulfide-bearing porphyritic shonkinite (Fig. 4c). In addition, there is a Pt peak at 60 $62 \mathrm{~m}$ which correlates with only a relatively small $\mathrm{Cu}$ enrichment (640 ppm).

In DD96MD002, the mineralised zone is thinner (located between 50 and $84 \mathrm{~m}$ depth in the core) and with generally lower $\mathrm{Cu}$ contents $\sim 500-1000$ ppm with a peak towards the base at $8100 \mathrm{ppm}$ (Fig. $4 \mathrm{~d}$ ). There is a small mineralised zone at 180-183 m with $\mathrm{Cu}$ up to $1850 \mathrm{ppm}$. Nickel (Fig. 4d) and $\mathrm{Co}$ (Fig. $4 \mathrm{e}$ ) correlate well with $\mathrm{Cu}$ in this case, and $\mathrm{Cr}$ shows a peak at the base of the mineralised zone that does not directly correlate with the base metals, although there is another peak at $180 \mathrm{~m}$ along with the $\mathrm{Cu}$ peak (Fig. 4e). Gold is consistently the most elevated of the precious metals and correlates well with $\mathrm{Cu}$, with the highest peak $(0.18 \mathrm{ppm})$ towards the base of the mineralised zone (Fig. 4f). Palladium and Pt also correlate well with $\mathrm{Cu}$, peaking at 0.058 and $0.1 \mathrm{ppm}$, respectively, at the base of the zone (Fig. 4f). There is an additional Aubearing zone which has no corresponding base or precious 
Fig. 3 Petrology of the host rock shonkinites. a Coarse-grained shonkinite with cumulus apatite (ap) and phlogopite (phl) with clinopyroxene (cpx), K-feldspar (Kfsp) and olivine (ol).

Transmitted light, plane polars. b Apatite-rich shonkinite with sulfide (sul). Transmitted light, plane polars. c Shonkinite with interstitial calcite (cc) adjacent to the margin of a sulfide bleb.

Transmitted light, crossed polars. d Sulfide bleb host to interstitial calcite in shonkinite. Transmitted and reflected light, crossed polars. e Porphyritic shonkinite containing large K-feldspar crystals. Transmitted light, plane polars. f Highly porphyritic shonkinite with large K-feldspar crystals surrounded by phlogopite-apatitesulfide. Transmitted light, plane polars
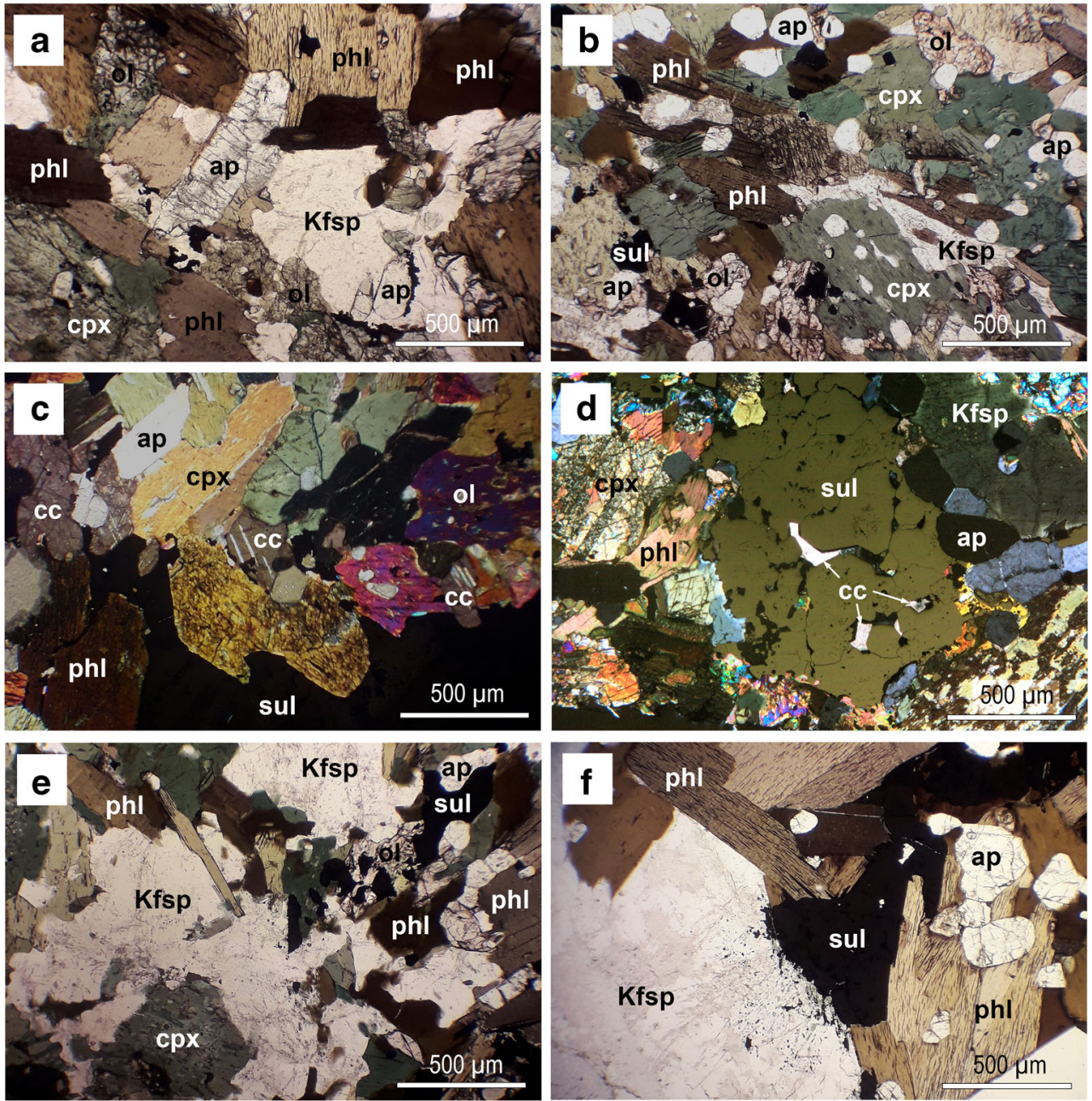

metals associated with it situated a few metres beneath the base of the main mineralised zone (Fig. 4f).

\section{Base and precious metal characteristics}

Figure 5 illustrates a range of base and precious metal relationships from DD96MD001 and DD96MD002. Copper and $\mathrm{Ni}$ (Fig. 5a) show a broad but slightly inconsistent relationship, with some of the mineralised samples containing significantly more $\mathrm{Cu}$ than $\mathrm{Ni}$ and plotting to the right of the general linear trend (Fig. 5a). The mean $\mathrm{Cu} / \mathrm{Ni}$ ratio in the mineralised zones is 6 , though the basal $7 \mathrm{~m}$ of the mineralised zone in DD96MD001 displays $\mathrm{Cu} / \mathrm{Ni}$ ratios that range from 11 to 25 (Supplementary Table 1). Chromium, as indicated in the downhole plots, does not show any relationship with $\mathrm{Cu}$ (Fig. 5b) but does show a weak correlation with $\mathrm{Ni}$, with the exception of the higher $\mathrm{Cr}$ samples (>200 ppm Cr) that show no relationship (Fig. 5c). It is worth noting from Fig. 4 that $\mathrm{Cr}$ is only elevated within and in close proximity to the mineralised zones. The best correlation within the base metals is between $\mathrm{Co}$ and $\mathrm{Ni}$ (Fig. 5d). Precious metals correlate poorly with the base metals, with the exception of $\mathrm{Cu}$ and Pd (Fig. 5e). Gold does not show any significant relationship with either $\mathrm{Cu}$ or Pd (Fig. 5f, g), and the Pt-Pd correlation is poor (Fig. 5h).

\section{Ore mineralogy/textural relationships of sulfides}

Sulfides are present as $<3 \mathrm{~cm}$ anhedral blebs that can make up to 10 modal \% of the shonkinites in the mineralised zones (Fig. 6a) at Braveheart. The sulfides are made up of mostly pyrite, with lesser chalcopyrite and minor millerite (Fig. 6b-f). Chalcopyrite is present both as interstitial phases to surrounding silicates and as anhedral inclusions in the pyrite (Fig. 6b, c, d) with some magnetite generally along the outer margins of the sulfide blebs, usually in contact with primary silicates and apatite (Fig. 6c). The only Ni-sulfide is millerite, which is present within the sulfide blebs as an interstitial phase to the pyrite grains (Fig. $6 \mathrm{~b}, \mathrm{c}, \mathrm{e}, \mathrm{f})$. In addition, the sulfide aggregates contain some gangue interstitial phases which are dominated by calcite (Fig. $6 e, f)$ and very minor barite and galena that are present as inclusions in pyrite (Fig. 6f). The drill cores were tested throughout for the presence of carbonate using $\mathrm{HCl}$, which revealed that calcite 


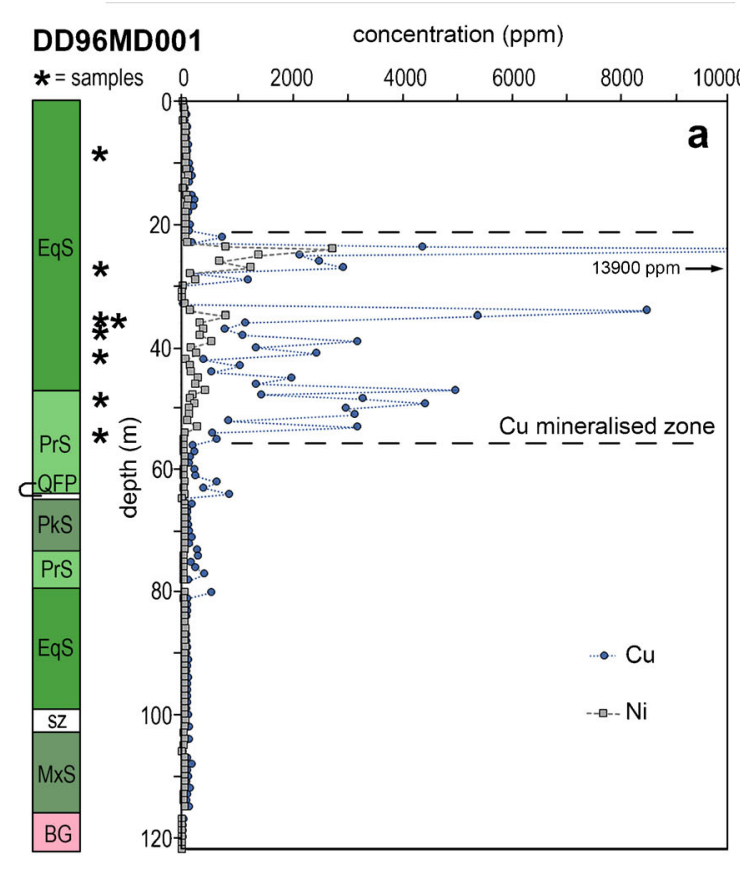

concentration (ppm)

concentration (ppm)
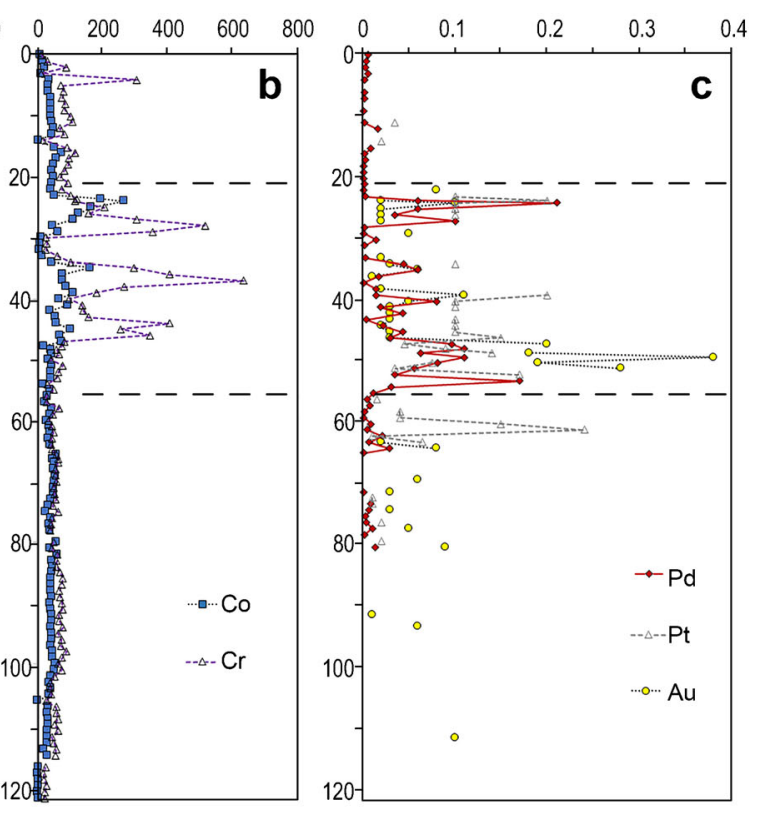

DD96MD002

concentration (ppm)

concentration (ppm)

concentration (ppm)
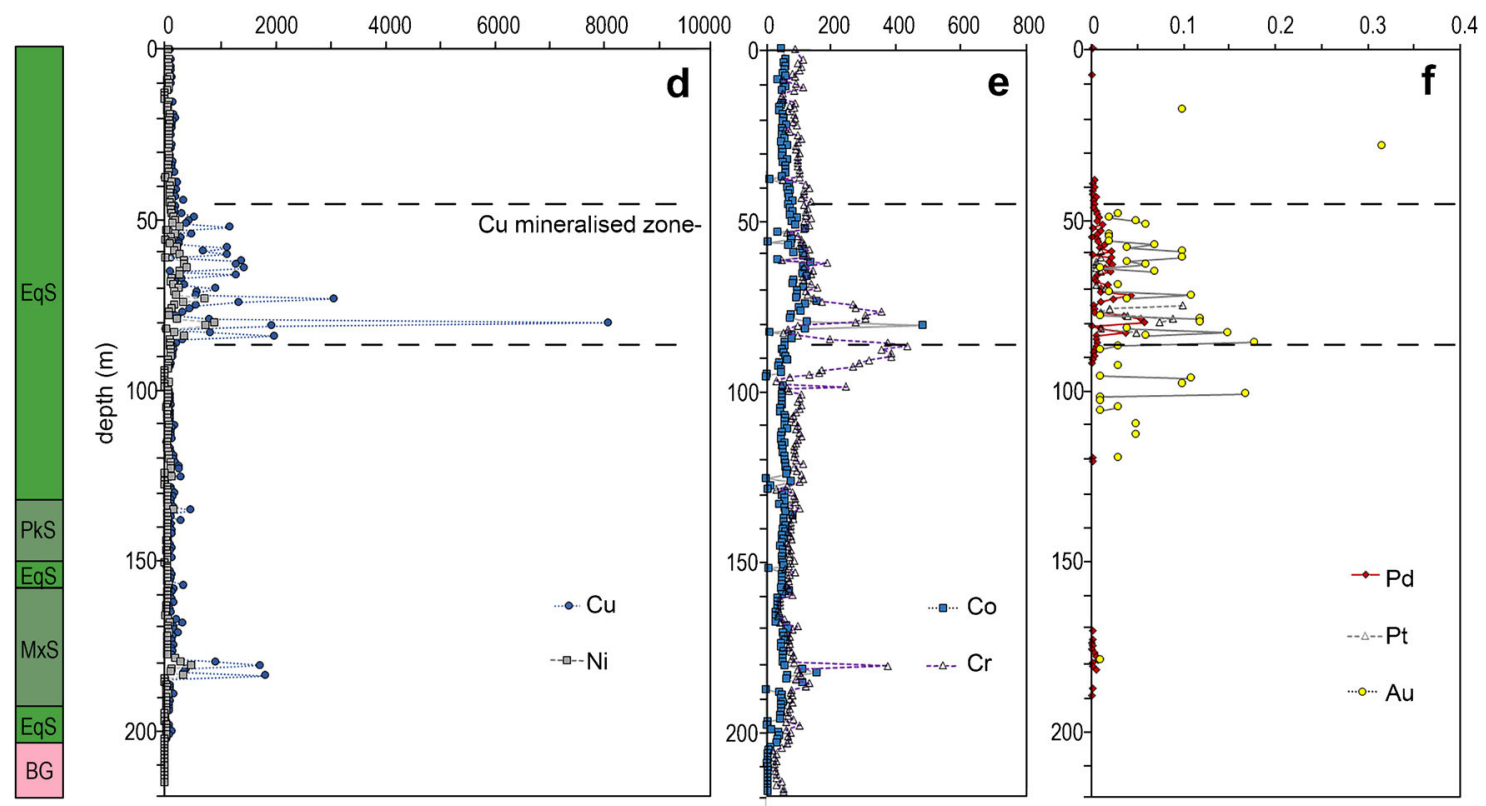

Key to lithologies: EqS = equigranular shonkinite; PrS = Porphyritic shonkinite; PkS = poikilitic shonkinite; MxS = mixed equigranular and poikilitic shonkinite; $\mathbf{B G}=$ basement gneiss/granite; $\mathbf{Q F P}=$ quartz-feldspar pegmatite; $\mathbf{s z}=$ shear zone (in shonkinite)

Fig. 4 Downhole concentrations of $\mathbf{a} \mathrm{Cu}$ and $\mathrm{Ni}, \mathbf{b} \mathrm{Co}$ and $\mathrm{Cr}$ and $\mathbf{c} \mathrm{Pt}, \mathrm{Pd}$ and $\mathrm{Au}$ from DD96MD001; and $\mathbf{d ~} \mathrm{Cu}$ and Ni, e $\mathrm{Co}$ and $\mathrm{Cr}$ and $\mathbf{f} \mathrm{Pt}, \mathrm{Pd}$ and Au from DD96MD002. Data and geological log from McCoy et al.

is strongly associated with sulfide blebs and is not a consistent part of the shonkinite assemblage.

Platinum and $\mathrm{Pd}$ are present as telluride minerals of the moncheite $\left(\mathrm{PtTe}_{2}\right)$-merenskyite $\left(\mathrm{PdTe}_{2}\right)$ solid solution series, along with some associated hessite $\left(\mathrm{Ag}_{2} \mathrm{Te}\right)$. The tellurides are usually present in clusters associated with the sulfide blebs, being
(1997). Asterisk denotes location of samples for petrological and mineralogical analysis in this study

in contact with chalcopyrite, or in some cases magnetite that forms rims around some of the sulfides (Fig. 7a, b), or as isolated 'satellite' grains with minor sulfide in close proximity to large sulfide-magnetite blebs (Fig. 7c). It is worth noting that although Fig. $7 \mathrm{a}$ and $\mathrm{b}$ show the PGM in contact with magnetite, they are still intimately associated with the sulfides on a 

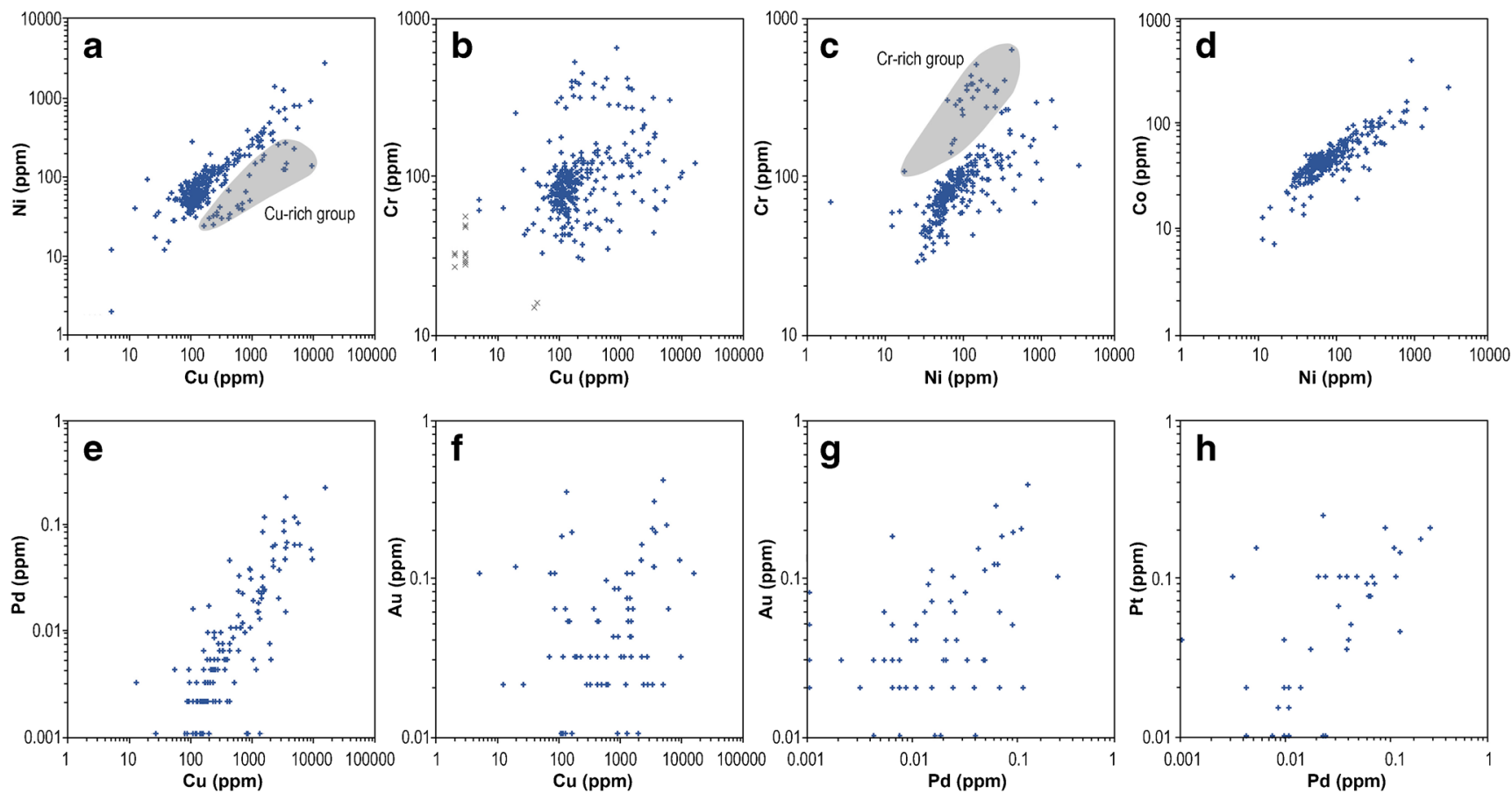

Fig. 5 Bulk rock geochemistry from DD96MD001 and DD96MD002: a Cu vs Ni, b Cu vs Cr, $\mathbf{c} \mathrm{Ni}$ vs $\mathrm{Cr}$, d Ni vs $\mathrm{Co}, \mathbf{e} \mathrm{Cu}$ vs $\mathrm{Pd}$, f Cu vs $\mathrm{Au}, \mathbf{g} \mathrm{Pd}$ vs Au and h Pd vs Pt. Data from McCoy et al. (1997)

Fig. 6 Sulfide mineralogy. a Blebby sulfides in shonkinite from drillcore DD96MD001. b and $\mathbf{c}$ Reflected light images of blebby sulfide with aggregates of idiomorphic pyrite (py) with interstitial and inclusions of chalcopyrite (cpy) and rarer interstitial millerite (mil) in shonkinite, with some magnetite (mt) at the margins of sulfides in contact with phlogopite (phl), apatite (ap) and hornblende (hnb). Inset shows detail of anhedral chalcopyrite inclusions. d Reflected light image of coarse-grained pyrite with chalcopyrite in shonkinite. $\mathbf{e}$ Reflected light image of bleb of idiomorphic pyrite with inclusions of chalcopyrite and minor interstitial millerite in shonkinite. f SEM backscattered image of area shown in e, showing interlocking, idiomorphic pyrite with inclusions of chalcopyrite and minor barite (bar) and galena (gn). Calcite (cc) is the interstitial phase (see also Fig. 3d)
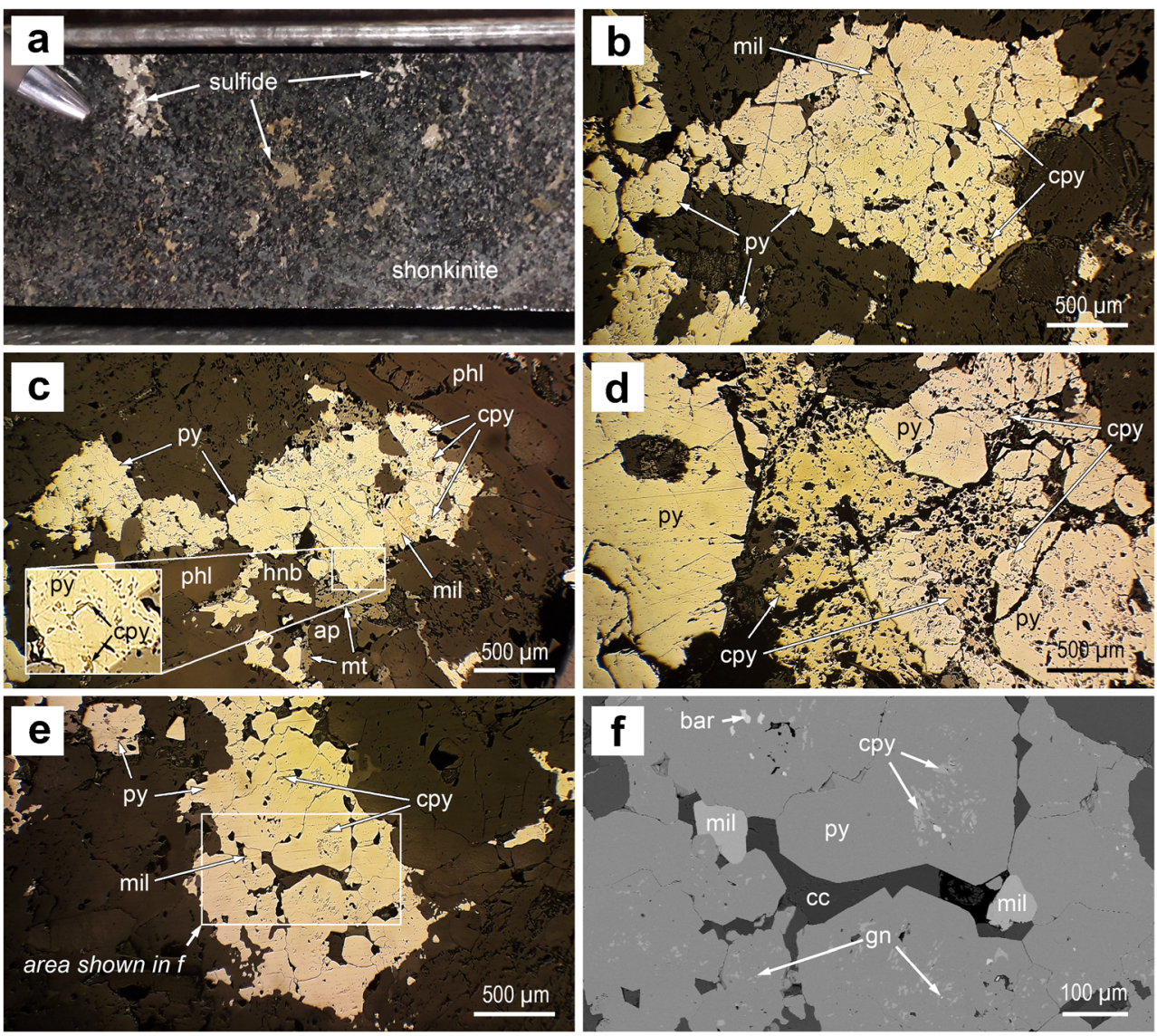

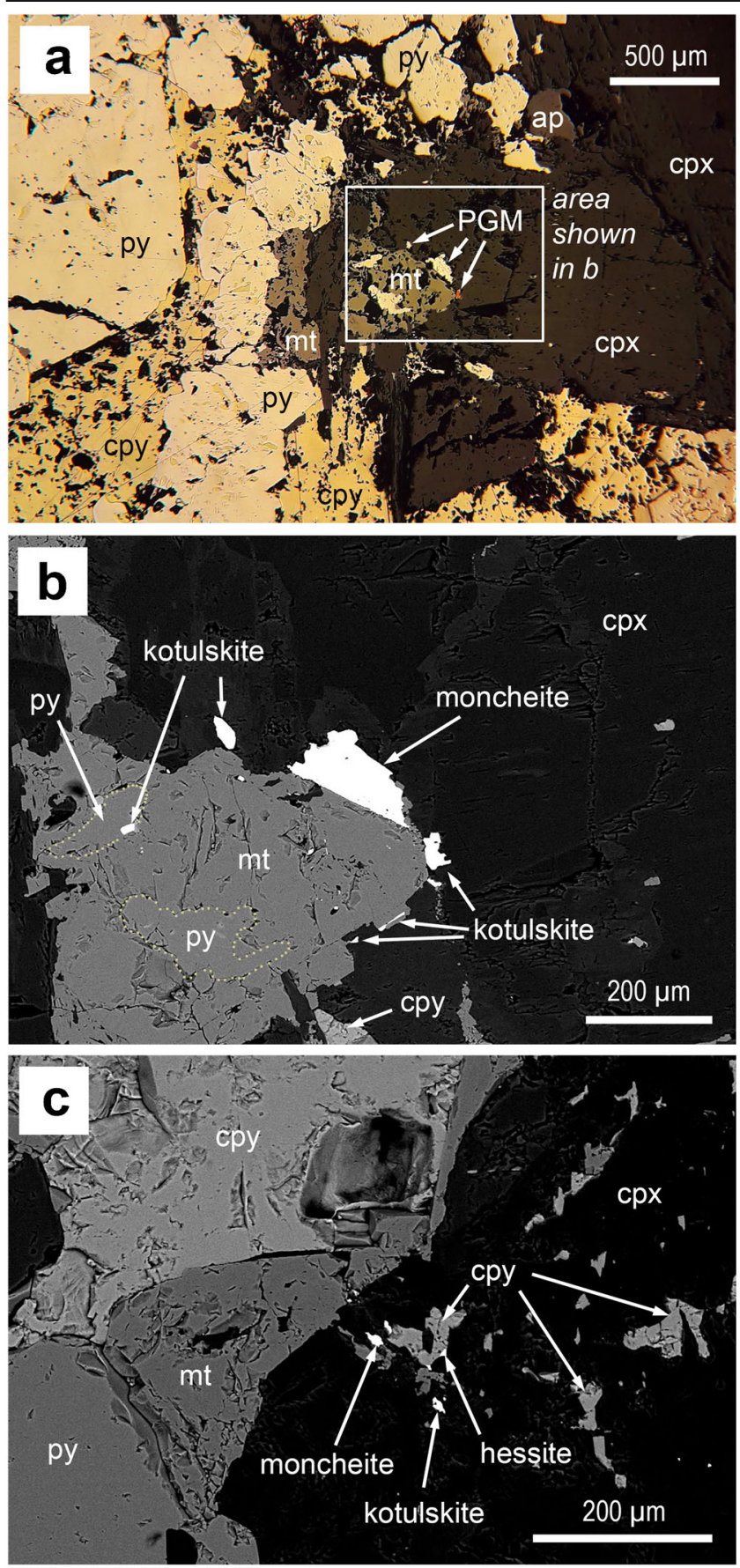

Fig. 7 Textural association of platinum-group minerals (PGM) in the Braveheart mineralisation. a Reflected light image of cluster of PGM associated with a magnetite ( $\mathrm{mt}$ )-pyrite (py) grain within clinopyroxene (cpx) and apatite (ap) adjacent to a large pyrite-chalcopyrite (cpy) bleb. b SEM backscattered electron image of the PGM cluster shown in a, showing a large moncheite grain and several kotulskite grains along the margins of magnetite-pyrite. c Cluster of moncheite, kotulskite and hessite with chalcopyrite adjacent to a pyrite-chalcopyrite-magnetite grain

submillimetre scale. The magnetite in Fig. $7 \mathrm{a}$ and $\mathrm{b}$ appears to be replacing pyrite, with anhedral pyrite 'islands' present in the centre of the magnetite, with the PGM remaining on the margins of the magnetite-pyrite grain.

\section{Discussion}

The magmatic sulfide mineralisation in the Braveheart area of the MAIC has a number of key characteristics that provide evidence for the processes and controls on magmatic sulfide mineralisation in the MAIC and alkaline igneous systems in general. These are:

- Blebby sulfides dominated by pyrite, with chalcopyrite and minor Ni-sulfides and Pt and Pd tellurides

- A Cu-Au-dominant (over Ni) chalcophile metal character

- A previously unrecognised association between sulfides and primary carbonate

Here we address these features in relation to the wider subject of magmatic sulfides in unconventional settings, specifically alkaline magmatic systems, and how Mordor fits within recent models for this style of mineralisation (Holwell et al. 2019; Hou and Wang 2019; Blanks et al. 2020); and discuss the origin of the MAIC itself.

\section{Nature of the sulfides at Braveheart, MAIC}

The mineralogy of most magmatic Ni-Cu-sulfide deposits is almost exclusively comprised of pyrrhotite-pentlanditechalcopyrite with some pyrite and magnetite (Barnes et al. 2017), which form from the fractionation and cooling of a sulfide liquid, with Pt and Pd most commonly forming tellurides, bismuthides and other semi-metal bearing minerals (Holwell and McDonald 2010). As such, the pyritedominant (>50\%) mineralogy at Braveheart, with an absence of pyrrhotite and pentlandite, does not conform to this classic style, though it does contain Pt-Pd-tellurides. Significant pyrite can form from the fractionation and cooling of a sulfide liquid if the $\mathrm{S}$ to metal ratio of the sulfide liquid is high enough $\left(\sim 40 \mathrm{wt} \% \mathrm{~S}\right.$ at $600{ }^{\circ} \mathrm{C}$ ), although the maximum amount of pyrite that can be accommodated by the breakdown of monosulfide solid solution at temperatures below $700{ }^{\circ} \mathrm{C}$ is around 30\% (Naldrett and Kullerud 1967; Kullerud 1969), which explains the presence of some primary magmatic pyrite identified in a number of deposits (e.g. the Great Dyke; Piña et al. 2016), but is still too low to account for the amounts seen in the Braveheart mineralisation. Millerite, which is the only $\mathrm{Ni}$-sulfide present at Braveheart, only forms as a primary product of mss in extremely $\mathrm{Ni}$-rich systems such as komatiites (Barnes et al. 2011), which clearly the MAIC is not, given the alkaline silicate mineralogy and the low $\mathrm{Ni}$ contents of the sulfides (Fig. 4). Millerite is, however, more common as a low temperature alteration product of primary pentlandite in the pyrite-millerite-chalcopyrite (PMC) alteration described by Holwell et al. (2017) and references therein. Indeed, experimental constraints suggest millerite and pyrite can only co-exist at temperatures below $230{ }^{\circ} \mathrm{C}$ (Naldrett 
and Kullerud 1967) and therefore the Braveheart mineralogy must be a low-temperature assemblage.

Although the Braveheart sulfide mineralogy is comparable to the PMC alteration style in terms of the sulfide minerals present, the textures displayed are completely different to those described by Holwell et al. (2017). At Braveheart, pyrite is idiomorphic with inclusions of chalcopyrite as it is at Sron Garbh (e.g. Fig. 8 in Graham et al. 2017). In contrast, the characteristics of the PMC alteration style are very ragged, amorphous pyrite and chalcopyrite intergrowths, rather than inclusions (e.g. Fig. 6 in Smith et al. 2011), with a reduction in sulfide grain size, shown by a rim of hydrous silicates such as quartz (Holwell et al. 2017), which is not observed in our samples (Fig. 3). Therefore, we do not suggest that the Braveheart mineralisation is the product of secondary, lowtemperature fluid alteration of a primary pentlanditepyrrhotite-chalcopyrite assemblage. Instead, it appears that this style of mineralisation may be a primary product of the magmatic fractionation of an $\mathrm{Fe}-\mathrm{Cu}$-dominant sulfide liquid, but with an atypical $\mathrm{S} / \mathrm{Fe} / \mathrm{Ni} / \mathrm{Cu}$ ratio (dominated by $\mathrm{Cu}$ and $\mathrm{S}$ ) that has produced the pyrite-chalcopyrite-(millerite) assemblage on cooling.

The PGM are located around the margins of the sulfide blebs, but do show some association with magnetite. We argue that the primary silicates and apatite in direct contact with sulfide margins do not support a hydrothermal alteration origin for the PGM, with no evidence of secondary silicates such as actinolitetremolite-talc that are very common around altered sulfides ( $\mathrm{Li}$ et al. 2004); rather, they crystallised as tellurides alongside the sulfides. The small amounts of magnetite located around the margins of some sulfides (Fig. 6c) are interpreted to be from the fractionation of the sulfide liquid, which commonly contains some dissolved $\mathrm{FeO}$, that forms magnetite as a minor product on cooling. As such, the pyrite-chalcopyrite-millerite-magnetitePGE telluride assemblage is considered to be a primary product of the cooling of a sulfide liquid, albeit at a low temperature. This contrasts with the compositionally similar Loch Borralan and Loch Ailsh alkaline ultramafic intrusions in Scotland, where sulfides and Sb-As-Te-bearing PGM are generally located along micro-shear zones, veins and late brittle fractures (Styles et al. 2004), indicative of a hydrothermal origin or modification. However, hydrothermal mobilisation of the sulfides and PGE at Loch Borralan and Loch Ailsh are restricted to pyroxenitic units and Styles et al. (2004) suggest any redistribution from an original magmatic assemblage to be on a centimetre to metre scale at most. Some of the metal ratios and distributions at Braveheart would support some fluid mobilisation, for example, the lack of correlation of Au with any other metals (Fig. 5) and the PGE and Au peaks towards the base of the mineralised zones in DD96MD001 that do not correspond to $\mathrm{Cu}$ peaks (Figs. $2 \mathrm{~b}$ and 4). It is likely though that the majority of the mineralisation is of a primary style, shown by the generally strong correlation in $\mathrm{Ni} / \mathrm{Cu}$ and $\mathrm{Cu} / \mathrm{Pd}$ ratios (Fig. 5a, e).

\section{Spatial relationships of the mineralisation}

The ultramafic rocks of the MAIC have been shown by Barnes et al. (2008) to be a layered sequence of cyclic units. The Braveheart area is close to the margin of the intrusion and the sulfide mineralisation is within $40 \mathrm{~m}$ of the contact with the host rock gneisses (Fig. 2). As such, rather than the 'reef' style mineralisation in layered cumulates at Mithril and Mt Doom, Braveheart is more similar in style to a 'contact' style of mineralisation, though it is not in immediate contact with the country rocks. It is worth noting that drillholes DD97MD003 and DD97MD004, drilled perpendicular to the intrusive contact, but collared closer towards the centre of the intrusive complex compared with DD96MD001 and DD96MD002 (Fig. 2a), did not intersect mineralisation, indicating that the mineralisation is probably localised and associated with the margin of the intrusion, and most likely marked by the gossanous ironstone at surface (Fig. 2b).

The mineralised zone at Braveheart coincides with some Cr-enriched lithologies on a broad scale (Fig. 4), although it is worth noting that $\mathrm{Cr}$ does not correlate whatsoever with $\mathrm{Cu}$ on a fine scale (Figs. 4 and 5), indicating no close spatial relationship between sulfides and $\mathrm{Cr}$-enriched lithologies. The bulk of the data do, however, show a good correlation between $\mathrm{Cr}$ and $\mathrm{Ni}$ (Fig. 5c) and $\mathrm{Co}$ in non-mineralised samples, which can be attributed to these elements being present as trace components in the mafic silicates such as olivine, pyroxene and phlogopite. However, where bulk $\mathrm{Cr}$ is above $200 \mathrm{ppm}$, it does not correlate with any of the base metals, which would be consistent with either the addition of small amounts of a phase with high $\mathrm{Cr}$ contents, such as chromite, or, perhaps less likely, a significant increase in the modal proportion of a phase that hosts $\mathrm{Cr}$ as a trace element, such as clinopyroxene. We therefore suggest that the shonkinites at Braveheart may have horizons/zones/pods with minor chromite, broadly correlating with the mineralised zone, but that $\mathrm{Cr}$-rich horizons have no fine scale control over the presence or concentration of base and precious metals.

Whilst Pt, Pd and Au show a broad correlation with the base metals, particularly Pd with $\mathrm{Cu}$ (Fig. 5e), there is no strong relationship between Pt and Au with any of the base metals or, indeed, the other precious metals (Figs. 4 and 5). Blebby mineralisation like that at Braveheart that we show does not conform to the fine-grained disseminated sulfides in 'offset reef' style deposits like Skaergaard (Andersen et al. 1998; Holwell and Keays 2014), Munni Munni (Barnes et al. 1990) and Sonju Lake (Li et al. 2008), which typically display $\mathrm{Cu}$-enriched zones stratigraphically above a distinct Au peak, which in turn is positioned above horizons of PGE enrichment. There is no systematic offset in the peaks in Fig. 4, but it is fair to say that the precious metals do not correlate fully with the base metals. In addition, there are some isolated PGE and/or Au peaks below the main mineralised zones. Rather than this being a magmatic 
offset, it is likely that the poor correlation between the metals in general is due to fluid interaction and redistribution on a metre scale during syn- or post-magmatic fluid interaction as discussed above. This is entirely plausible given the hydrous/volatile-rich nature of the magmas as demonstrated by the presence of abundant hydrous silicates like phlogopite and calcite associated with the sulfide.

\section{Comparison with other mid-crustal alkaline-hosted magmatic sulfide occurrences}

Mordor contains two separate styles of magmatic sulfide mineralisation: blebby, $\mathrm{Cu}$-rich mineralisation hosted by the marginal shonkinites that we describe in this paper, and the stratiform-disseminated PGE-rich style in the ultramafics at Mithril that Barnes et al. (2008) described. There are relatively few lamprophyric mafic-ultramafic intrusions with magmatic sulfide mineralisation, although one notable exception, in addition to Mordor, is the Sron Garbh intrusion, Scotland (Graham et al. 2017). This, along with a few other alkaline ultramafic intrusions in Scotland (Loch Borralan and Loch Ailsh; Gunn and Styles 2002; Styles et al. 2004), contains magmatic $\mathrm{Cu}-\mathrm{Ni}-\mathrm{PGE}$ sulfides. In addition, Sron Garbh has been used as an example of a mid-crustal alkaline intrusion in the studies on the chalcophile element 'DNA' of postsubduction magmatism (Holwell et al. 2019) and the link between carbonate and sulfide in magmatic systems (Blanks et al. 2020).

The mafic-ultramafic rocks of Mordor and Sron Garbh are comparable, both being plutonic lamprophyric intrusions emplaced into the mid-crust. In detail, the host rocks to the mineralisation differ a little, with the Sron Garbh host rocks being appinites, composed of amphibole cumulates with interstitial phlogopite, calcite, quartz and K-feldspar. However, the sulfide mineralisation style is highly comparable being dominated by pyrite and chalcopyrite with only minor Ni-phases that characteristically do not include pentlandite, with $\mathrm{Ni}$ present in gersdorffite (NiAsS) at Sron Garbh and millerite at Mordor. Texturally, the sulfide blebs are also remarkably similar, with blebby pyrite at Sron Garbh containing inclusions of chalcopyrite (Fig. 8A and B in Graham et al. 2017) identical to those seen at Braveheart in Mordor (Figs. 6b-f and 7a). In addition, the PGE are present as tellurides, which is a characteristic of Sron Garbh and a number of other alkaline igneous rock-hosted intrusions (Holwell et al. 2019).

Furthermore, the chalcophile element geochemistry of the Mordor mineralisation at both Braveheart and Mithril is similar in many ways to Sron Garbh. Primitive mantle-normalised chalcophile element profiles for Braveheart, Mithril and Sron Garbh are shown in Fig. 8 for comparison. The variability in $\mathrm{Cu} / \mathrm{Au}$ ratio at Braveheart (Fig. 5f) is shown by the lack of parallelism in the profiles between $\mathrm{Au}$ and $\mathrm{Cu}$. However, in general, the profiles show a positive trend from Pt through to

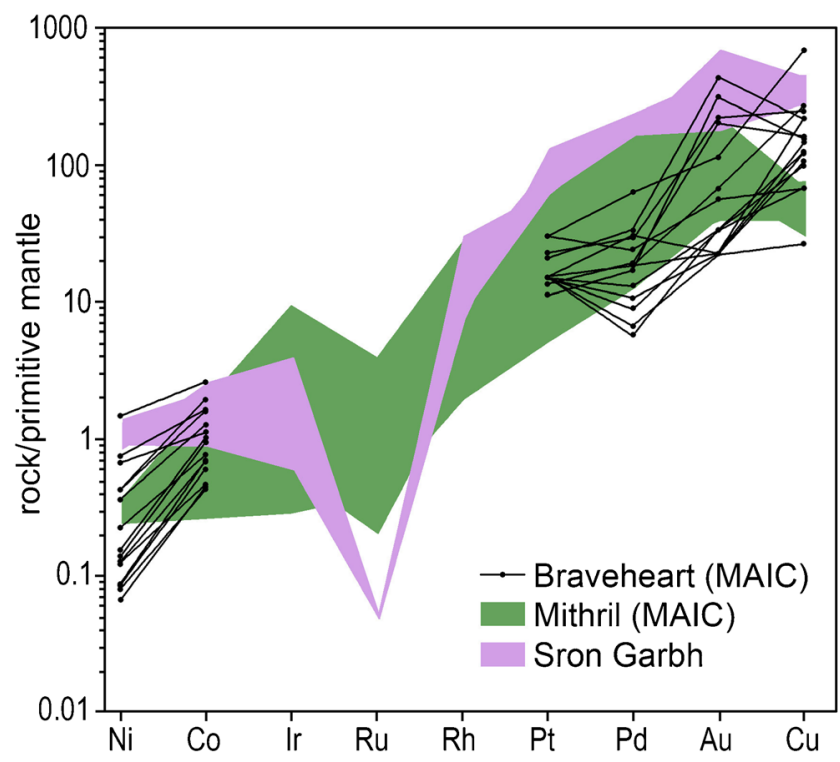

Fig. 8 Primitive mantle-normalised chalcophile element profiles for samples from the mineralised zone in DD96MD001 from Braveheart in the MAIC which contain $\mathrm{Ni}, \mathrm{Co}, \mathrm{Pt}, \mathrm{Pd}, \mathrm{Au}$ and $\mathrm{Cu}$ all above detection limits. Fields for the Mithril PGE prospect in the ultramafic rocks of the MAIC (Barnes et al. 2008) and the Sron Garbh intrusion, Scotland (Graham et al. 2017), are shown for comparison. Primitive mantle normalising values from Palme and O'Neill (2004)

$\mathrm{Pd}$ and from $\mathrm{Au}$ to $\mathrm{Cu}$, with a peak at $\mathrm{Au}$, or more commonly $\mathrm{Cu}$. This reflects a very $\mathrm{Cu}$-dominant chalcophile element character, in comparison with the more precious metal-dominant Mithril stratiform and Sron Garbh prospects that peak at $\mathrm{Au}$ and have a negative slope from $\mathrm{Au}$ to $\mathrm{Cu}$. That said, all three prospects are all relatively $\mathrm{Cu}-\mathrm{Au}$-rich compared with more conventional Ni-Cu-PGE deposits that generally display arched profiles with a peak at Pt or Pd (e.g. Barnes and Ripley 2016). The steep-normalised chalcophile element patterns (and thus high $\mathrm{Pd} / \mathrm{Ir}$ ratios) can be explained by incongruent melting of mantle sulfide during low-degree partial melting, which liberates $\mathrm{Pt}, \mathrm{Pd}$ and $\mathrm{Au}$ but retains much of the $\mathrm{Ir}, \mathrm{Ru}$ and $\mathrm{Rh}$ in residual monosulfide solid solution (Holwell et al. 2019), and as such, steep profiles like those shown in Fig. 8 for Mordor and Sron Garbh are characteristic of sulfide-bearing alkaline systems.

\section{The significance of carbonate in alkaline-hosted $\mathrm{Cu}$ - Au-Te(-Ni-PGE) sulfide mineralisation}

The association of Au- and Te-rich epithermal mineralisation associated with alkaline magmas has been recognised for some time (Jensen and Barton 2000). Richards (2009) proposed that first-stage arc magmas generate $\mathrm{Cu}$-rich porphyry systems, leaving an Au-rich residue in the lower crust, and second-stage partial melting of the residual sulfide produces Au-rich magmas, with relatively high $\mathrm{Au} / \mathrm{Cu}$ ratios, using this as an explanation as to why post-subduction, alkaline magmas form porphyry $\mathrm{Cu}-\mathrm{Au}$ deposits. Holwell et al. (2019) proposed that the characteristic 
$\mathrm{Cu}-\mathrm{Au}$-Te-rich magmatic sulfide mineralisation and the upper crustal epithermal deposits were a product of a number of factors including (1) a metasomatised mantle source; (2) partial or incongruent melting of sulfides in the mantle source (which may already may have a high $\mathrm{Au} / \mathrm{Cu}$ ratio in the way Richards (2009) proposed); and (3) partial sulfide dissolution in the mid to upper crust.

Further recent advances outlined in Blanks et al. (2020) also show that in volatile-rich mafic-alkaline systems, carbonate appears to be intimately associated with sulfide, particularly in the lower and mid-crust, and may play a crucial role in fluxing metalrich sulfides from the mantle into the crust. The sulfide in these systems typically have a very $\mathrm{Cu}-\mathrm{Au}$-Te-rich metal character, hosted by rocks that possess a hydrous and carbonated mineralogy (as seen at Braveheart by the large amounts of phlogopite and carbonate). Carbonate in the shonkinites at Braveheart is strongly associated with sulfide, as interstitial phases within sulfide blebs (Fig. 6e, f) and as a part of the shonkinitic host rock only close to the margins of sulfide blebs (Fig. 3c). Our identification of significant carbonate with the sulfides adds a further distinct association to the four types of carbonate occurrence identified by Langworthy and Black (1978) in the Mordor Complex and represents the most primary magmatic style. The intra-sulfide bleb textures imply that carbonate may have been included within the sulfide liquid droplets, or possibly even exsolved from the sulfide liquid on cooling. This is also seen in lower crustal alkaline ultramafic pipes at Valmaggia, NW Italy (Sessa et al. 2017; Blanks et al. 2020), and to a certain extent, in the lamprophyric Sron Garbh intrusion, Scotland (Graham et al. 2017; Blanks et al. 2020).

The model of Blanks et al. (2020) advocates that supercritical $\mathrm{CO}_{2}$ acts as a physical buoyancy aid to sulfide droplets as they ascend from the mantle source into the lower crust (seen by carbonate present with cuspate boundaries around sulfide blebs in the lower crust; Sessa et al. 2017; Blanks et al. 2020), but that this association will become weaker with ascent as $\mathrm{CO}_{2}$ becomes more volatile and sulfide becomes more soluble (Mavrogenes and O'Neill 1999; Kamenetsky and Yaxley 2015). The evidence from Mordor, an example of a classic mid-crustal intrusion, would be consistent with this model whereby some carbonate remains associated with blebby sulfides along the intrusion margin at this crustal depth. The clear textures that indicate wetting of $\mathrm{CO}_{2}$ and sulfide liquid in the lower crust are not present, but full maturity to separated $\mathrm{CO}_{2}$ and dissolved sulfide has not yet occurred. We propose that Mordor contains magmatic sulfide blebs at Braveheart that were transported, possibly rapidly, from their mantle source in association with supercritical $\mathrm{CO}_{2}$. This can explain the apparent paradox of centimetre-scale dense sulfide globules being transported upwards, rather than sinking (Lesher 2019), as the low density of the $\mathrm{CO}_{2}$ is sufficiently high to overcome the relative density contrast between the sulfide and the silicate melt.
Blanks et al. (2020) suggested that during magma ascent, sulfide and carbonate will separate and the association will diminish so that in the upper crust, the association is unlikely to be preserved. How the carbonate will manifest subsequent to separation is unclear, but it is most likely that it forms late-stage carbonaterich hydrothermal veins, or even carbonatitic intrusions. It is worth noting that some, or all, of the four occurrences of carbonate identified by Langworthy and Black (1978) may be the result of either separation or later remobilisation of mantle carbonate originally brought in with the mafic-ultramafic magmas. Perhaps most intriguing is the presence of a circular carbonate plug in the northeastern part of the mafic-ultramafic complex (Fig. 2a), which may represent a late-stage intrusion (or expulsion) of more carbonatitic fluids/melts. Its size and location, a few tens of metres outside the margin of the mafic-ultramafic complex, bears resemblance to the Loch Urigill carbonatite in Scotland, which is thought to be a late-stage derivative of the Loch Borralan alkaline complex (Young et al. 1994). Further work would be required to ascertain a similar origin for the Mordor plug, but the context now presented from the Blanks et al. (2020) model raises the possibility such features represent carbonate sinks from an initially $\mathrm{CO}_{2}$ rich alkaline mafic-ultramafic magma.

The evidence put forward for the $\mathrm{CO}_{2}$-driven physical transport by Blanks et al. (2020) involves exclusively blebby styles of mineralisation along the margins of lower and mid-crustal intrusions. Therefore, whilst this mechanism may be a key factor in transporting the sulfide blebs into the Braveheart zone at the margins of the Mordor Complex, the genesis of the disseminated reef-style deposits in the Mithril area warrants some further discussion as Mordor appears to be unique amongst the range of alkaline intrusions with magmatic sulfide mineralisation in having both styles. According to Barnes et al. (2008), the reef mineralisation is formed from late-stage magma pulses intruded into a complex that already contained earlier formed cumulates. As such, this would place the Braveheart sulfides as an early phase, consistent with them being driven up by buoyant $\mathrm{CO}_{2}$ and crystallising along the margins of the intrusion, as they have at Sron Garb (Graham et al. 2017), for example.

The magma composition controls the likelihood for continued saturation in $\mathrm{CO}_{2}$ on ascent from a mantle source. Low-degree, alkaline melts should remain saturated in $\mathrm{CO}_{2}$ for longer than higher degree melts like tholeiites, if saturated. This is because $\mathrm{CO}_{2}$ is highly incompatible during mantle melting (Rosenthal et al. 2015); therefore, its initial concentration in the melt would be at its highest and reduces with an increasing degree of partial melting. Thus, the more ultramafic magmas that were then injected at Mordor likely did not contain large, or even any, compound $\mathrm{CO}_{2}$-sulfide droplets upon emplacement, and either (1) were already sulfide saturated with small droplets of moderately PGEenriched sulfides that settled in to the reefs or (2) became sulfide saturated in the Mordor chamber and were trapped in layered cumulates (Barnes et al. 2008). Therefore, there may not be a direct genetic relationship between the two styles of 
mineralisation but instead, the complex records two separate mechanisms for fluxing and concentrating magmatic sulfides.

\section{Implications for the setting and origin of the MAIC}

The tectono-magmatic setting of the MAIC is currently unclear, and it has a unique emplacement date in the Arunta region, compared with other mafic-ultramafic rocks (Fig. 1a). The MAIC shares similar chalcophile element geochemistry to other alkaline-hosted magmatic sulfide deposits that are related to post-collisional extension events, which have evidence of subduction metasomatism in the source. As such, it is tempting to suggest this for the MAIC as well, although no firm hypothesis for a post-subduction setting has thus far been presented. Nelson et al. (1989) provided Sm and Nd isotopic evidence that the MAIC was generated from an enriched mantle source emplaced in an intracratonic setting, though did not expand on this to suggest the enrichment may have been from subduction metasomatism.

The timing of intrusion coincides with the regional 1150 $1130 \mathrm{Ma}$ 'Teapot' magmatic event in the southern Arunta Orogen (Collins and Shaw 1995), thought to represent a transition from extension to intraplate magmatism (Claoué-Long and Hoatson 2005). What has not been noted, but bears some consideration, is the remarkable similarity in the circular shape, and outward zonation of dunites, clinopyroxene-phlogopite cumulates, shonkinites and syenites, with the intraplate, zoned alkaline ultramafic intrusions found in the Aldan Shield in Russia, such as the Kondyor and Inagli intrusions which produce platiniferous and auriferous placers (Burg et al. 2009; Svetlitskaya et al. 2018). The genesis and setting of these zoned alkaline-ultramafic intrusions themselves is contentious, though has been suggested to represent diapirs of lithospheric mantle rocks (Burg et al. 2009).

Langworthy and Black (1978) note late-stage veinlets of calcite-rich, apatite-phlogopite-bearing serpentinised breccia and dyke-like bodies of phlogopite-calcite rock at Mordor. These may be of a similar origin to the glimmerite and 'koswite' (i.e. phlogopite-amphibole-apatite-carbonate and $\mathrm{Fe}$-Ti-oxide clinopyroxenite) dykes in the Kondyor massif (Burg et al. 2009). Furthermore, at Kondyor, there are late-stage nephelinesyenitic and carbonatitic melts generated upon differentiation of the primary lamproite melt. It may be that some of the carbonatebearing veins and dykes that cross cut the MMUI have a similar, late-stage origin, from the differentiation of the main lamprophyric mafic-ultramafic body. The circular nature of the MAIC, zonation and layering within the MMUI and its petrology alongside the alkaline nature of the rocks and the presence of carbonate with chalcophile element mineralisation are all comparable to the pipe-like, intracratonic, alkaline-ultramafic Aldan Shield intrusions. Notwithstanding this possibility, in any case, Mordor compounds the observed association of carbonate with sulfide in mafic-ultramafic-alkaline intrusions.

\section{Summary}

Mordor is perhaps the type example of a large, mid-crustal alkaline mafic-ultramafic intrusion with magmatic sulfide mineralisation. The nature of the sulfides, as $\mathrm{Cu}-\mathrm{Au}$-rich compared with $\mathrm{Ni}$ and PGE, the alkaline and hydrous nature of the host rocks, and an association of the sulfide with primary carbonate, all support recent models of mantle-to-crust fluxing of chalcophile metals with $\mathrm{S}$ and $\mathrm{C}$ in relatively low-degree partial melt magmatic systems. As such, Mordor illustrates that alkaline igneous rocks are prospective for magmatic $\mathrm{Cu}-\mathrm{Au}-\mathrm{PGE}-\mathrm{Ni}$ sulfide mineralisation and that the classic marginal, sulfide-rich and stratiform sulfide-poor mineralisation styles are possible in such intrusions. Furthermore, we propose that the Mordor Alkaline Igneous Complex may represent a Proterozoic, mid-crustal equivalent of the zoned alkaline-ultramafic pipes found in the Aldan Shield and, as such, extend the $\mathrm{Cu}-\mathrm{Au}$-Te-carbonate 'metallogenic DNA' signature proposed for post-subduction alkaline systems to intracratonic setting alkaline systems.

Acknowledgements Maxwell Heckenberg and Jay Carter at the NTGS core facility in Alice Springs are thanked for facilitating access and assisting with the sampling of drill cores. We also fully acknowledge the exploration work by CRAE in 1996 and 1997, from which the samples and assay data within this paper are used. Constructive reviews by Eduardo Mansur, Rubén Piña and Associate Editor Wolfgang Maier are acknowledged for helping improve the quality of the manuscript and depth of discussion.

Open Access This article is licensed under a Creative Commons Attribution 4.0 International License, which permits use, sharing, adaptation, distribution and reproduction in any medium or format, as long as you give appropriate credit to the original author(s) and the source, provide a link to the Creative Commons licence, and indicate if changes were made. The images or other third party material in this article are included in the article's Creative Commons licence, unless indicated otherwise in a credit line to the material. If material is not included in the article's Creative Commons licence and your intended use is not permitted by statutory regulation or exceeds the permitted use, you will need to obtain permission directly from the copyright holder. To view a copy of this licence, visit http://creativecommons.org/licenses/by/4.0/.

\section{References}

Andersen JC, Rasmussen H, Nielsen TF, Ronsbo JG (1998) The Triple Group and the Platinova gold and palladium reefs in the Skaergaard Intrusion; stratigraphic and petrographic relations. Econ Geol 93:488-509

Anderson J, Smith T (2003) First annual report EL10404 Mordor for year ending 20 May 2003. Tanami Gold NL

Barnes S-J, Ripley EM (2016) Highly siderophile and strongly chalcophile elements in magmatic ore deposits. Rev Mineral Geochem 81:725-774

Barnes J, McIntyre JR, Nisbet BW, Williams CR (1990) Platinum group element, mineralisation in the Munni Munni Complex, western Australia. Mineral Petrol 42:141-164

Barnes SJ, Anderson JAC, Smith TR, Bagas L (2008) The Mordor Alkaline Igneous Complex, Central Australia: PGE-enriched disseminated sulfide layers in cumulates from a lamprophyric magma. Mineral Deposita 43:641-662 
Barnes SJ, Godel BM, Locmelis M, Fiorentini ML, Ryan CG (2011) Extremely Ni-rich Fe-Ni sulfide assemblages in komatiitic dunite at Betheno, Western Australia: results from synchrotron X-ray fluorescence mapping. Aust J Earth Sci 58:691-709

Barnes SJ, Cruden AR, Arndt N, Saumur BM (2016) The mineral system approach applied to magmatic $\mathrm{Ni}-\mathrm{Cu}-\mathrm{PGE}$ sulphide deposits. Ore Geol Rev 76:296-316

Barnes SJ, Holwell DA, Le Vaillant M (2017) Magmatic sulfide ore deposits. Elements 13:89-95

Barraclough D (1981) Final report on the Mordor Complex, Central Australia. Northern Territory Survey Rep GS81-48:

Begg GC, Hronsky JA, Arndt NT et al (2010) Lithospheric, cratonic, and geodynamic setting of Ni-Cu-PGE sulfide deposits. Econ Geol 105: $1057-1070$

Black LP, Shaw RD, Stewart AJ (1983) Rb-Sr geochronology of Proterozoic events in the Arunta Inlier, central Australia. BMR J Aust Geol Geophys 8:129-138

Blanks DE, Holwell DA, Fiorentini ML, Moroni M, Giuliani A, Tassara S, González-Jiménez J-M, Boyce AJ, Ferrari E (2020) Fluxing of mantle carbon as a physical agent for metallogenic fertilisation of the crust. Nat Commun 11:4342. https://doi.org/10.1038/s41467-020-18157-6

Burg J-P, Bodinier J-L, Gerya T, Bedini RM, Boudier F, Dautria JM, Prikhodko V, Efimov A, Pupier E, Balanec JL (2009) Translithospheric mantle diapirism: geological evidence and numerical modelling of the Kondyor zoned ultramafic complex (Russian Far-East). J Petrol 50:289-321

Claoué-Long JC, Hoatson DM (2005) Proterozoic mafic-ultramafic intrusions in the Arunta Region, central Australia: part 2: Event chronology and regional correlations. Precambrian Res 142:134-158

Collins WJ, Shaw RD (1995) Geochronological constraints on orogenic events in the Arunta Inlier: a review. Precambrian Res 71:315-346

Cordier C, Coin K, Arndt NT, Cartigny P (2019) The Älgliden Ni-Cu-Au deposit: magmatic sulfides in a subduction setting. Mineral Deposita 55:1173-1196. https://doi.org/10.1007/s00126-019-00921-4

Deng Y-F, Song X-Y, Chen L-M, Zhou T, Pirajno F, Yuan F, Xie W, Zhang $\mathrm{D}$ (2014) Geochemistry of the Huangshandong $\mathrm{Ni}-\mathrm{Cu}$ deposit in northwestern China: implications for the formation of magmatic sulfide mineralization in orogenic belts. Ore Geol Rev 56:181-198

Graham SD, Holwell DA, McDonald I, Jenkin GRT, Hill NJ, Boyce AJ, Smith J, Sangster C (2017) Magmatic Cu-Ni-PGE-Au sulfide mineralisation in alkaline igneous systems: an example from the Sron Garbh intrusion, Tyndrum, Scotland. Ore Geol Rev 80:961-984

Gunn AG, Styles MT (2002) Platinum-group element occurrences in Britain: magmatic, hydrothermal and supergene. Appl Earth Sci 111:2-14

Heaman LM, Machado N (1992) Timing and origin of midcontinent rift alkaline magmatism, North America: evidence from the Coldwell Complex. Contributions to Mineralogy and Petrology 110 (2-3): 289-303

Hoatson DM, Sun S, Claoué-Long JC (2005) Proterozoic mafic-ultramafic intrusions in the Arunta Region, central Australia: part 1: Geological setting and mineral potential. Precambrian Res 142:93-133

Holwell DA, Keays RR (2014) The formation of low-volume, high-tenor magmatic PGE-Au sulfide mineralization in closed systems: evidence from precious and base metal geochemistry of the Platinova Reef, Skaergaard Intrusion, East Greenland. Econ Geol 109:387-406

Holwell DA, McDonald I (2010) A review of the behaviour of platinum group elements within natural magmatic sulfide ore systems. Platin Met Rev 54:26-36

Holwell DA, Adeyemi Z, Ward LA, Smith DJ, Graham SD, McDonald I, Smith JW (2017) Low temperature alteration of magmatic Ni-Cu-PGE sulfides as a source for hydrothermal Ni and PGE ores: a quantitative approach using automated mineralogy. Ore Geol Rev 91:718-740

Holwell DA, Fiorentini ML, McDonald I, Lu Y, Giuliana A, Smith DJ, Keith M, Locmelis M (2019) A metasomatized lithospheric mantle control on the metallogenic signature of post-subduction magmatism. Nat Commun 10:3511. https://doi.org/10.1038/s41467-019-11065-4
Hou Z, Wang R (2019) Fingerprinting metal transfer from mantle. Nat Commun 10:1-3. https://doi.org/10.1038/s41467-019-11445-w

Jensen EP, Barton MD (2000) Gold deposits related to alkaline magmatism: Society of Economic Geologists Reviews, v 13

Kamenetsky VS, Yaxley GM (2015) Carbonate-silicate liquid immiscibility in the mantle propels kimberlite magma ascent. Geochim Cosmochim Acta 158:48-56

Kullerud G (1969) Phase relations in the $\mathrm{Cu}-\mathrm{Fe}-\mathrm{S}, \mathrm{Cu}-\mathrm{Ni}-\mathrm{S}$ and $\mathrm{Fe}-\mathrm{Ni}-\mathrm{S}$ system. Magmat Ore Depos pp 323-343

Langworthy AP, Black LP (1978) The Mordor Complex: a highly differentiated potassic intrusion with kimberlitic affinities in central Australia. Contrib Mineral Petrol 67:51-62

Lesher CM (2019) Up, down, or sideways: emplacement of magmatic $\mathrm{Fe}-\mathrm{Ni}-\mathrm{Cu}-\mathrm{PGE}$ sulfide melts in large igneous provinces. Can J Earth Sci 56:756-773

Li C, Ripley EM, Merino E, Maier WD (2004) Replacement of base metal sulfides by actinolite, epidote, calcite, and magnetite in the UG2 and Merensky Reef of the Bushveld Complex, South Africa. Econ Geol 99:0173-0184

Li C, Ripley EM, Oberthür T, Miller JD Jr, Joslin GD (2008) Textural, mineralogical and stable isotope studies of hydrothermal alteration in the main sulfide zone of the Great Dyke, Zimbabwe and the precious metals zone of the Sonju Lake Intrusion, Minnesota, USA. Mineral Deposita 43:97-110

Lu Y, Lesher CM, Deng J (2019) Geochemistry and genesis of magmatic Ni-Cu-(PGE) and PGE-(Cu)-(Ni) deposits in China. Ore Geol Rev

Maier WD, Groves DI (2011) Temporal and spatial controls on the formation of magmatic PGE and Ni-Cu deposits. Mineral Deposita 46:841-857

Maier WD, Andreoli MA, Groves DI, Barnes S-J (2012) Petrogenesis of $\mathrm{Cu}-\mathrm{Ni}$ sulphide ores from O'okiep and Kliprand, Namaqualand, South Africa: constraints from chalcophile metal contents. South Afr J Geol 115:499-514

Makkonen HV, Halkoaho T, Konnunaho J, Rasilainen K, Kontinen A, Eilu P (2017) Ni-(Cu-PGE) deposits in Finland-geology and exploration potential. Ore Geol Rev 90:667-696

Mavrogenes JA, O'Neill HSC (1999) The relative effects of pressure, temperature and oxygen fugacity on the solubility of sulfide in mafic magmas. Geochim Cosmochim Acta 63:1173-1180

McCoy AD, Wilkinson DL, Louwrens DJ (1997) EL 9371 Mordor Pound, N.T. First annual report for year ending 6th January 1997. CRA Explor Pty Ltd

Naldrett AJ, Kullerud G (1967) A study of the Strathcona mine and its bearing on the origin of the nickel-copper ores of the Sudbury district, Ontario. J Petrol 8:453-531

Nelson DR, Black LP, McCulloch MT (1989) Nd-pb isotopic characteristics of the Mordor Complex, northern territory: mid-proterozoic potassic magmatism from an enriched mantle source. Aust J Earth Sci 36:541-551

Palme H, O’Neill HSC (2004) C. 2014. Cosmochemical estimates of mantle composition. Treatise Geochem Oxf Elsevier-Pergamon, pp 1-39

Piña R, Romeo I, Ortega L et al (2010) Origin and emplacement of the Aguablanca magmatic Ni-Cu-(PGE) sulfide deposit, SW Iberia: a multidisciplinary approach. Bulletin 122:915-925

Piña R, Gervilla F, Barnes S-J, Oberthür T, Lunar R (2016) Platinumgroup element concentrations in pyrite from the Main Sulfide Zone of the Great Dyke of Zimbabwe. Mineral Deposita 51:853-872

Richards JP (2009) Postsubduction porphyry $\mathrm{Cu}-\mathrm{Au}$ and epithermal $\mathrm{Au}$ deposits: products of remelting of subduction-modified lithosphere. Geology 37:247-250

Rosenthal A, Hauri EH, Hirschmann MM (2015) Experimental determination of $\mathrm{C}, \mathrm{F}$, and $\mathrm{H}$ partitioning between mantle minerals and carbonated basalt, $\mathrm{CO} 2 / \mathrm{Ba}$ and $\mathrm{CO} 2 / \mathrm{Nb}$ systematics of partial melting, and the $\mathrm{CO} 2$ contents of basaltic source regions. Earth Planet Sci Lett 412:77-87

Rudashevsky NS, Kretser YL, Rudashevsky VN, Sukharzhevskaya ES (2004) A review and comparison of PGE, noble-metal and sulphide mineralization in phoscorites and carbonatites from Kovdor and Phalaborwa. 
Phoscorites Carbonatites Mantle Mine Key Ex Kola Alkaline Prov Eds F Wall Zaitev Mineral Soc G B Irel Lond, pp 375-405

Sessa G, Moroni M, Tumiati S, Caruso S, Fiorentini ML (2017) Ni-Fe$\mathrm{Cu}$-PGE ore deposition driven by metasomatic fluids and melt-rock reactions in the deep crust: the ultramafic pipe of Valmaggia, IvreaVerbano, Italy. Ore Geol Rev 90:485-509

Smith JW, Holwell DA, McDonald I (2011) The mineralogy and petrology of platinum-group element-bearing sulphide mineralisation within the Grasvally Norite-Pyroxenite-Anorthosite (GNPA) member, south of Mokopane, northern Bushveld Complex, South Africa. Appl Earth Sci 120:158-174

Styles MT, Gunn AG, Rollin KE (2004) A preliminary study of PGE in the Late Caledonian Loch Borralan and Loch Ailsh alkaline pyroxenite-syenite complexes, north-west Scotland. Mineral Deposita 39:240-255
Svetlitskaya TV, Nevolko PA, Kolpakov VV, Tolstykh ND (2018) Native gold from the Inagli Pt-Au placer deposit (the Aldan Shield, Russia): geochemical characteristics and implications for possible bedrock sources. Mineral Deposita 53:323-338

Tolkien JRR (1954) The Lord of the Rings. Allen and Unwin

Wilkinson DL, Home DP, Noel E (1998) Mordor Pound No. 2 EL 9371 Second and final annual report for the year ending 5 November, 1997. Rio Tinto Explor Pty Ltd, Belmont

Young BN, Parsons I, Threadgould R (1994) Carbonatite near the Loch Borralan intrusion, Assynt. J Geol Soc 151:945-954

Publisher's note Springer Nature remains neutral with regard to jurisdictional claims in published maps and institutional affiliations. 